Sandro Nielsen*

\title{
Bilingual Dictionaries for Communication in the Domain of Economics: Function-Based Translation Dictionaries
}

\begin{abstract}
With their focus on terms, bilingual dictionaries are important tools for translating texts on economics. The most common type is the multi-field dictionary covering several related subject fields; however, multi-field dictionaries treat one or few fields extensively thereby neglecting other fields in contrast to single-field and sub-field dictionaries. Furthermore, recent research shows that economic translation is not limited to terms so lexicographers who identify and analyse the needs of translators, usage situations and stages in translating economic texts will have a sound basis for designing their lexicographic tools. The function theory allows lexicographers to study these basics so that they can offer translation tools to the domain of economics. Dictionaries should include data about terms, their grammatical properties, and their combinatorial potential as well as language varieties such as British, American and international English to indicate syntactic options and restrictions on language use. Secondly, translators need to know the meaning of domain-specific terms to properly understand the differences in the structure of the domains in the cultures involved. Finally, pragmatic data will tell authors and translators how textual resources are conventionally used and what is textually appropriate in communication within the field of economics. The focus will mainly be on translations between Danish and English.
\end{abstract}

\section{Introduction}

Being able to communicate correctly about economic issues in international contexts is an ability that has been in high demand for some time, in particular due to increased litigation and regulation in the wake of the financial crisis. An important part of this communication takes place in or originates from English either as texts written directly in English or as texts translated into or from English and the actors involved in economic communication in international settings need dictionaries that can help them produce factually and idiomatically correct translations of economic issues. However, when translating from and into English, translators regularly consult bilingual dictionaries and often find that these do not meet their requirements. As Baskerville/Evans (2011: 9) point out, one reason is that "meaning is culture-dependent, and there is rarely a one-to-one correspondence, or an exact overlap of vocabulary in different cultures". Bilingual dictionaries often lack the specialisation required by professional translators, and dictionaries of economics should be tools that can help translators prepare the message they need to convey to the intended audiences.

Those involved in economic discourse form a heterogeneous group. Businesses publish financial reports in order to attract investors, and banks partly base their decisions to grant loans and credit lines on such reports. Similarly, economists, governments and supranational institutions use economic data to implement policies and action plans, which often leads to regulatory frameworks within which individuals, enterprises, governmental and inter-governmental agencies have to conduct their affairs. It is important that those actors are able to communicate about economic issues in a way that is factually as well as linguistically correct. In order to make the necessary dictionaries, lexicographers should establish a sound theoretical and practical basis for bilingual

\footnotetext{
* Sandro Nielsen

Centre for Lexicography, Aarhus University

Department of Business Communication

Jens Chr. Skous Vej 4

8000 Aarhus $C$

Denmark

sn@bcom.au.dk
} 
dictionaries of economics designed to help translators communicate correctly: The dictionaries must represent fairly the factual, terminological and linguistic state of affairs relevant to inter-lingual economic discourse. The aim of this paper is to identify the theoretical and practical basis of electronic and printed bilingual dictionaries of economics treating primarily the languages of English and Danish by discussing the scope of lexicography and types of dictionaries, by analysing the needs of translators using the theory of lexicographic functions, by briefly discussing relevant elements in the translation process and then identify some of the types of data needed by translators.

\section{Defining the scope of lexicography}

There is no doubt that lexicography and lexicographic principles can help facilitate economic communication. Theoretical lexicography, such as the function theory, focuses on the development of principles for information tools that provide needs-adapted information, but this has not always been the case. Tarp/Bothma (2013) trace the development of lexicography from the Age of Enlightenment to the present and their findings are relevant when trying to specify how lexicography can help international economic discourse. During the Age of Enlightenment, lexicography appears to have supported the dissemination of knowledge about language and factual matters with a didactic touch: "we see a vision of dictionaries as tools designed not only to explain words but also to disseminate knowledge and science as well as to teach and instruct people how to perform within a wide range of activities" (Tarp/Bothma 2013: 224). This statement shows that lexicography had a relatively broad scope of application and that lexicographers intended to make dictionaries that provide help with facts and practical issues in, for instance, business and economic communication. This situation seems to have changed around the time Samuel Johnson published his Dictionary of the English Language in 1755. Tarp/Bothma (2013: 225) find that "Samuel Johnson works with a much narrower concept [of dictionary] than other authors from the same century. In his view, a dictionary is apparently only about words".

The narrow, linguistically-oriented scope of lexicography gradually replaced that of the Enlightenment Age and had great influence on the production of dictionaries for some 200 years. During this period, conventional wisdom dictated that dictionaries should be regarded as repositories of knowledge about language and this focus on words meant that most lexicographers excluded from their dictionaries factual and practical issues relevant to business people and economists acting in non-linguistic environments despite the increasing importance of these specialised domains in personal, national and international contexts.

The impression is that champions of Enlightenment were no longer seen as leading lexicographers and that this role had been taken over by linguists occupied with words. The scope of lexicography seems to have become increasingly limited so that lexicographers were not the first port of call for economists when they needed dictionaries. One reason for the narrow scope may be that lexicographers were influenced by a state of affairs resembling what has later been called the McNamara fallacy, named after the US secretary of defence Robert McNamara and used to explain why US forces "lost" the Vietnam War and had to withdraw in the 1970s. The fallacy goes as follows:

1. The first step is to measure whatever can be easily measured. This is $\mathrm{OK}$ as far as it goes.

2. The second step is to disregard that which cannot be easily measured or to give it an arbitrary quantitative value. This is artificial and misleading.

3. The third step is to presume that what cannot be measured easily is not important. This is blindness.

4. The fourth step is to say that what cannot be easily measured really does not exist. This is suicide.

(Yankelovich quoted in Smith 1972: 281-282) 
If it is applied to lexicography, the McNamara fallacy can perhaps help explain why lexicography was and by some still is seen as a linguistic activity and that this approach to lexicography is somewhat unsatisfactory, for example:

1. Linguists (lexicographers) measure mainly language dictionaries. This is $\mathrm{OK}$ as far as it goes

2. Linguistics (lexicography) can analyse language but not facts and practical matters. This is artificial and misleading

3. Only linguistic issues are important. This is blindness

4. Only language dictionaries exist. This is suicide

If they see lexicography as a linguistic activity, it is easy to understand why economists may think that lexicography has little to offer. If lexicographers practice applied linguistics and economists need dictionaries that can provide help with words as well as facts, why would they turn to lexicographers for help? Economists may feel that they can do the job themselves since facts and practical issues form the main subject-matter of dictionaries of economics. However, a brief study of existing bilingual dictionaries shows that economists could learn a thing or two from modern lexicography. Figures 1 and 2 contain excerpts from a Swedish-English/English-Swedish dictionary of economics prepared by the Institute for the Accounting Profession in Sweden.

\begin{tabular}{|ll|}
\hline pant & collateral \\
& pledge \\
& security \\
& pawn \\
& mortgage \\
& deposit \\
\hline
\end{tabular}

Figure 1. The article pant in Fars Engelska Ordbok

The article in Figure 1 presents a number of problems. First, the English equivalents listed in apparently random order are not full synonyms because they refer to different concepts and can therefore not be used interchangeably. Moreover, the terms pledge and pawn are synonyms and refer to a security right where the lender has possession of the asset given as security. This should be contrasted with the term mortgage, which is a security right characterised by the fact that the asset given as security remains in the possession of the borrower. Finally, immovable property such as land and buildings can be mortgaged but not pledged, whereas movable property such as watches can be either mortgaged or pledged. As the dictionary does not explain such details, dictionary users are given no help if they want to find the correct English translation of the Swedish term pant. Figure 2 is equally unhelpful and the authors should explicitly have stated that the English term price is used about financial instruments such as shares, while the term rate is used about foreign currency. The lack of help to distinguish between the concepts involved and their equivalents described above diminishes the value and usefulness of the dictionary as a translation tool.

\begin{tabular}{|ll|}
\hline kurs & $\begin{array}{l}\text { price } \\
\text { rate }\end{array}$ \\
\hline
\end{tabular}

Figure 2. Excerpt from the article kurs in Fars Engelska Ordbok

One reason for the unhelpful lexicographic treatment identified in Figures 1 and 2 may be that the authors of the dictionary used a linguistically inspired semasiological approach with focus on words in linguistic systems instead of a terminologically inspired onomasiological approach 
that focuses on concepts within a specific domain and its conceptual and terminological systems (Kageura 2015: 53-54). As pointed out by Felber (1984: 168), focus on terms "implies that it is necessary to refer to extra-linguistic factors in order to define the concept of a term adequately". Application of an onomasiological approach based on conceptual structures would have resulted in two or more articles with the lemma pant and two articles with the lemma kurs. The English equivalents would then have been distributed to the appropriate articles according to proper term/ concept relationships, thereby providing functionally relevant help to users.

Through the function theory, lexicography is now moving towards a position which resembles that found during the Age of Enlightenment; Figures 1 and 2 thus do not represent best practice in lexicography (see Section 3 for a discussion of the function theory). As reported by Tarp/Bothma (2013: 282) "many principles developed in the 18th century have been forgotten - many of which are highly relevant to lexicography in the Age of Internet", and present-day lexicography has readopted a broad scope in order to develop and produce information tools that can satisfy the needs of economists and translators when translating words, terms, concepts, facts and practical matters.

\section{Identifying relevant types of dictionary}

Lexicographers categorise specialised dictionaries in various ways. Wiegand (1988: 762-778) and Felber/Schaeder (1998: 1730-1731), among others, distinguish between dictionaries that contain data on non-linguistic aspects, dictionaries that contain data on linguistic aspects, and dictionaries that contain data on both linguistic and non-linguistic aspects relating to one or more domains. Others base their typologies on formal and structural categories (Andersen/Fuertes-Olivera 2009: 214-216), while some use the number of languages as a criterion and divide dictionaries into monolingual, bilingual and multilingual reference works. These typologies merely indicate that dictionaries deal with one, two or more languages and that they contain various types of data; the typologies do not indicate how and in what situations dictionaries can help users, or for whom they provide assistance. However, lexicographers have proposed other typologies that are relevant from both a theoretical and a practical point of view.

Two typologies are particularly relevant for dictionaries of economics. Nielsen (1990: 132135) distinguishes between multi-field dictionaries, which cover two or more subject fields such as the typical business dictionary containing terms from a range of domains, e.g. economics, insurance, law and marketing, and single-field dictionaries, which cover only one subject field, such as a dictionary of economics. Single-field dictionaries can be either general-field dictionaries, each covering an entire subject field such as a dictionary of economics, or sub-field dictionaries, each covering one sub-field within a general field, for instance a dictionary of accounting.

Single-field and general-field dictionaries can better provide the help users need than multifield dictionaries. General-field dictionaries can contain more entry words, or lemmas, than subfield dictionaries, so their scope of use is larger than that of sub-field dictionaries as they cover entire subject areas. Nevertheless, sub-field dictionaries tend to treat the sub-fields concerned in more detail; a sub-field can be covered more extensively and detailed than a general field in the same number of pages or bytes. Finally, sub-field dictionaries are good tools for providing help in translation situations because, unlike multi-field and general-field dictionaries, they can contain more data that provide help in respect of economic concepts, economic terms, semi-economic terms, general vocabulary, derivation, grammatical irregularity, definitions, translation equivalents, cultural and factual differences, translation of collocations, and textual conventions in economic usage.

Secondly, dictionaries of economics can have one or more types of function. According to the theory of lexicographic functions, a dictionary function is the satisfaction of specific types of lexicographically relevant need of specific types of potential user in specific types of extralexicographic situation (Bergenholtz/Tarp 2010: 30). Lexicographic functions can be described as responses to real-life problems in a non-lexicographic environment, such as problems arising 
during a translation task. Lexicographic functions can be divided into general types, of which the following two are those best described in the literature. Dictionaries that have communicative functions are designed to satisfy user needs in communicative usage situations, for instance by providing help to produce economic texts, to translate economic texts into or from a foreign language, and to help understand economic texts. Dictionaries may also have cognitive functions in which case they may provide help to acquire general factual knowledge about the field of economics or one of its sub-fields, to acquire specific factual knowledge about an economic topic, and to acquire general or specific knowledge about the language and conventions used in economics. As translation dictionaries have a communicative function, lexicographers should consider examining the extra-lexicographic process of translation in order to provide the help needed by economic translators with particular focus on single-field and sub-field dictionaries (see also Hatim/Mason (1997: 1-11) for a discussion of translation as an act of communication).

\section{The translation process in brief}

Dictionaries providing help to translate economic texts will need to contain several types of data that enable users to translate economic texts correctly in terms of grammar and style without compromising the factual contents. The general purpose of dictionaries intended for translation is to help users make acceptable translations and this means dealing with grammatical, syntactic, stylistic, conceptual and terminological issues that need to be addressed during the translation process. The lexicographic objective is to provide help in communicative usage situations that makes it possible for dictionary users to actively translate economic texts. There are several detailed descriptions of translation and scholars such as Bell (1991: 20-21), Gerzymisch-Arbogast (2008: 42-45) and Newmark (1988: 11-37) provide an overall description of a translation process that includes a decoding, or reception, phase, where translators discover semantic meaning and extra-linguistic sense from the source text, a transfer phase, where translators transfer the deduced meaning and sense from one language to another through comparative analyses, and an encoding, or (re)formulation, phase, where translators (re)formulate and write the target text, i.e. the product of translation.

The decoding, or reception, phase is the proper place to begin the discussion of translating economic texts. Firstly, translators need to properly understand the substantive message of source texts in order to attempt to render their contents in another language. Semantic meaning refers to the meaning of words as lexical units in linguistic systems while extra-linguistic sense has to be made of terms that represent concepts in structural systems within the domain of economics, i.e. terms are lexical units within extra-linguistic systems and refer to facts as well as practical matters. Secondly, by analysing source texts, translators will be able to identify genres and sub-genres within the domain of economics, which may help them understand the function(s) of the texts and guide them towards the correct solutions during the transfer and encoding phases. Accordingly, dictionaries that contain data on conceptual and terminological structures within the subject-field of economics can facilitate the translation of economic texts (see also Sections 5.1-5.4 below). As the decoding phase is only one element of translating, lexicographers should find a method that covers other steps in the translation process that is relevant to and workable in lexicography.

The transfer phase is where translators decide how the meaning of the decoded source text can best be moved from source-language to target-language at a general level. This will often involve the use of specific translation strategies related to the function and genre of source texts as well as the identification of those target-language terms and concepts that match those of the source language. The transfer phase may be seen as an extension of the decoding phase and a preliminary step towards passing a message from one language to another before the actual text is produced in another language.

A rough outline of the encoding, or (re)formulation, phase may illustrate the lexicographic choices that compilers of dictionaries of economics have to make. At its very basis "Translation - far from being a text transfer on the language level - is text production, presenting a message 
that was understood from another text" (Stolze 2003: 202). As translation is one form of text production, using an outline made by experts who have carefully studied and analysed text production and relating this to the translation process is one such workable method. Nielsen (2006: 49) and Marsen (2013:2) explain that the process of writing and translating texts can be divided into a planning, a drafting and a revising/editing stage. Dictionaries are not usually appropriate tools for providing help in the planning stage, since this is better covered by translation and writing manuals. The authors of dictionaries of economics intended for translation should therefore focus on the drafting and the revising/editing stages. Marsen (2013: 261-262) shows that, once written, the draft text should be revised and edited, and that proofreading concludes the revising/editing stage. Dictionaries of economics for translation should thus be regarded as information tools that can help translators decode source texts linguistically, factually and terminologically as well as draft, revise and edit translation texts.

The tasks of drafting, revising and editing are carried out at two levels. At the macro-level, translators work with background domain knowledge, paragraphs and larger units of text. Background knowledge within a domain involves knowledge of how concepts relate to each other and relations between concepts (see Section 5.3 below). The understanding of concept systems and relations helps translators identify cohesive elements in source texts, compare the systems and relations between the two cultures involved in the decoding and transfer phases (Suonuuti 1997: 11-15). At the micro-level, translators work with words, terms, collocations, phrases, sentences, and textual conventions (see e.g. Gerzymisch-Arbogast 2008: 15-16, 35-39). The micro-level is particularly relevant to dictionaries of economics because translators need help at this level when translating economic texts from or into a foreign language. Mossop (2014: 42-58) explains that when they revise and edit, translators make sure they have followed generally accepted grammar and spelling rules (grammar and syntax), have used words or terms consistently and correctly (lexis and syntax), have adopted appropriate textual conventions (pragmatics), and that the finished texts are unambiguous. The importance of the micro-level is also highlighted by Bowker (2012: 381), who argues that translators require skills and knowledge about various aspects of target-text production, including knowledge of target-language spelling, grammar, varieties, style, collocations, phrases and pragmatics (see also Sections 5.5 and 5.6 below). It follows that translators of economic texts face challenges 1) in the decoding, transfer and encoding phases and 2) at the macro-level and the micro-level of text production; lexicographers should therefore focus on these phases and levels when selecting data for single-field and sub-field dictionaries.

\section{Identifying required data types for translating}

The usefulness of translation dictionaries of economics depend on their capability of supporting the translation process. As indicated in Section 4, it is necessary to examine the extra-lexicographic translation activity with special reference to the domain of economics in an attempt to identify some of the needs translation dictionaries must satisfy to help users produce acceptable translations.

One way of identifying translator needs is to ask translators themselves. Recent studies, e.g. Baskerville/Evans (2011), Evans et al. (2011), Károly (2011), Chifane (2012), Dahlgren/Nilsson (2012), and Greko (2012) have examined the process of translating economic texts by surveying translator students and professional translators. One drawback with surveys is that the number of respondents in each study is often so small that the results are not representative. Nevertheless, the findings of the studies combined with the translation research discussed in Section 4 do indicate some of the real needs of student and professional translators of economic texts, and these findings may help lexicographers identify lexicographically relevant types of user need.

Translators of economic texts do not merely need language competence; they should also be able to understand the facts and practical matters underlying the message to be conveyed. Károly (2011) examines the needs of students who translate economic texts with European Union relevance and finds that: 
In many cases, the students had to draw on their extra-linguistic sub-competence and use their encyclopedic, thematic and bicultural knowledge [...] In the retrospective interviews, the students often referred to the lack of this knowledge as being at the root of their translation errors. (Károly 2011: 44)

The need for extra-linguistic knowledge is corroborated by findings reported in Baskerville/ Evans (2011), who studied the needs of professional translators working with international accounting standards. In connection with the use of dictionaries, referred to as "glossaries", their study found:

\footnotetext{
That 'the glossary is empty of context' is a concern for one respondent. This resonates with concerns expressed in other disciplines where dictionary translations or bilingual encyclopedias are often seen as misleading, because they do not address the fact that meanings are culture-dependent. (Baskerville/ Evans 2011: 34)
}

Findings such as these indicate that lexicography should have a broad scope that applies to words, terms and facts, because the narrow focus on words is not able to provide the dictionaries needed by student and professional translators. Lexicographers adopting a broad scope of application and focussing on single-field and sub-field dictionaries can provide the required help to translators working in the field of economics. The following sections discuss selected aspects of translation that are relevant to lexicographers and their dictionaries intended to help translators of economic texts.

\subsection{Lexicographers and translators need factual knowledge}

Definitions in translation dictionaries are important because translators translate economic concepts, not terms or words. In this context, definitions can be said to specify the meaning of concepts, while terms are expressions of language that refer to concepts. The term definition here refers to "the specific set of data that explains the meaning of a lemma and which is clearly addressed to the lemma" (Nielsen 2011: 202). Translators need definitions of economic concepts in order to ascertain that the lemmas, or entry words, and the equivalents in dictionaries have the correct meanings in the relevant contexts. In addition, definitions in bilingual dictionaries may help translators properly understand source texts. Lexicographers should, therefore, be sure that the meaning explanations they provide are factually correct; and when writing definitions for translation dictionaries within e.g. the sub-field of accounting, lexicographers can find definitions of concepts in the International Financial Reporting Standards (IFRS), which all business enterprises quoted on stock exchanges in the European Union must comply with. The standards are originally written in English and then translated into the other 23 official EU languages. It follows from this that a Danish-English translation dictionary should contain definitions of all lemmas to help translators understand source texts and find the correct meanings. The Danish definitions of IFRS concepts should be based on the Danish translations of the IFRSs, but as pointed out by Baskerville/Evans (2011), an important risk is involved:

\footnotetext{
Because languages are indeterminate and meanings between different languages do not exactly overlap, translators have to interpret the original meaning; there is therefore a risk that they do not capture the meaning intended by the standard setter. (Baskerville/Evans 2011: 6)
}

Translators of the IFRSs may fail to "capture the meaning intended" when terms in the source language have multiple meanings. One such case concerns the concept "separate vehicle" (Danish: saerskilt formidlende virksomhed), which is defined in IFRS 11. Lexicographers who have to provide a useful explanation of the concept should first consult the Danish and the English definitions, and the latter reads as follows:

separate vehicle: A separately identifiable financial structure, including separate legal entities or entities recognised by statute, regardless of whether those entities have a legal personality. (International Accounting Standards Board, 2011b: Appendix A. Underlining added) 
The underlined word presented the authors of the Danish-English accounting dictionary, DanskEngelsk Regnskabsordbog, with a challenge because it has been wrongly translated into Danish. An onomasiological approach reveals that the English term statute refers to two relevant concepts: 1) document that regulates the internal affairs of an organisation, similar to articles of association in UK companies; and 2) generally applicable rules of legislation, also referred to as law (see e.g. Oxford Business English Dictionary for learners of English). The Danish definition in IFRS 11 uses the term vedtcegter, which corresponds to concept 1 . In order to try to solve this problem, the Danish lexicographers then consulted the Swedish translation of IFRS 11, as the two languages are closely related, and there they found that statute had been translated bolagsordning, also a term corresponding to concept 1 . The lexicographers then looked at other translations of the standard which they could properly understand and there found that those translations had adopted concept 2, for example: French: défini par la loi; German: rechtlich anerkannte; Spanish: reconocidas por ley. Lexicographers may reasonably conclude that the Danish and Swedish translations are wrong, because it makes more sense that regulators decide in which situations an entity is a separate vehicle rather than leaving the decision to the organisation itself. To deal with wrong translations in regulatory texts, the Danish lexicographers elected to write a Danish definition in the dictionary that differs slightly from the official Danish one and to include a lexical note explaining why, as illustrated in Figure 3.

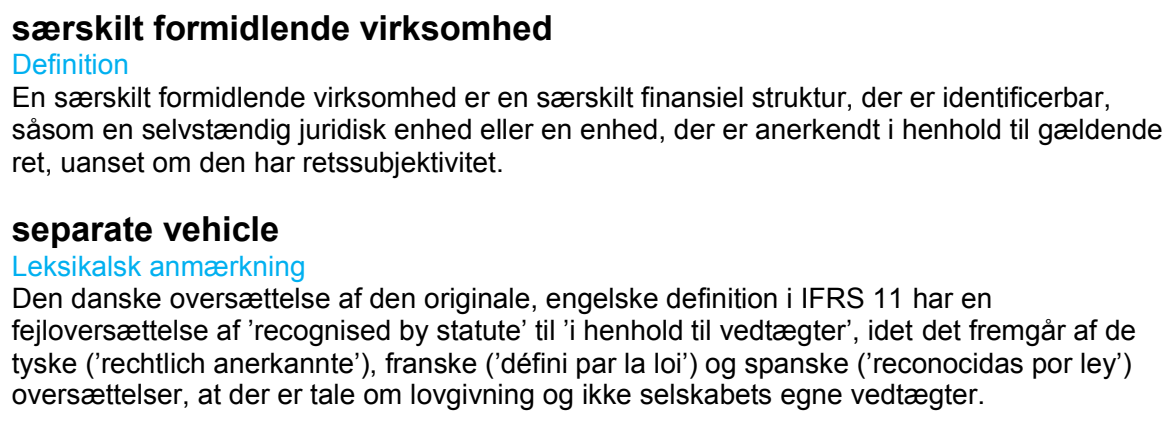

Figure 3. Definition and lexical note explaining mistranslation in international standard in Dansk-Engelsk Regnskabsordbog

The lexical note below the English equivalent can be rendered as follows: The Danish translation of the original English definition in IFRS 11 wrongly translates recognised by statute into $i$ henhold til vedtcegter, as it appears from the German (rechtlich anerkannte), French (défini par la $l o i$ ) and Spanish (reconocidas por ley) translations that the reference is to legislation and not the company's own articles of association. The note in Figure 3 explains why the dictionary definition differs slightly, but importantly, from the official Danish definition by placing the term in its extra-linguistic context, and reassures those who know the official definition that they have indeed found the right concept. But new concepts and terms may require special attention for other reasons.

\subsection{New concepts and terms may challenge the knowledge of lexicographers}

We live in a dynamic world with the result that new concepts, terms and words are introduced almost every day in many different domains. This is in line with the statement by Newmark (1988: 32) that "the chief difficulties in translation are lexical not grammatical - i.e. words, collocations and fixed phrases or idioms; these include neologisms." Lexicographers therefore have to keep up with this development where terms for new concepts are introduced and new terms replace old ones. In most cases this is a relatively easy task but, occasionally, new terms and concepts present interesting challenges to the skills and knowledge of lexicographers and translators. In the sub-field of financial reporting, standard setters recently replaced the long-standing term minority 
interest with the term non-controlling interest in International Accounting Standard (IAS) 27 as amended and International Financial Reporting Standard (IFRS) 10 because the new concept and its related term are more precise (International Accounting Standards Board 2009 and 2011a). The two standards were translated into Danish, and non-controlling interest was translated into minoritetsinteresse. Since that is also the Danish term for minority interest, it is difficult to see that Danish translations and Danish texts on the topic will be more precise as we are dealing with two different concepts. Again the Danish translation differs from that of other EU languages: Minority interests are called Minderheitsanteile in German, interest minoritaires in French, and intereses minoritaios in Spanish; while non-controlling interests are called nicht beherrschende Anteile (German), participations ne donnant pas le contrôle (French), and participations no dominantes (Spanish). That the concept of non-controlling interest differs from the concept of minority interest is important:

\footnotetext{
A parent entity does not have to hold 50 per cent or more of the equity capital of a subsidiary to control it. Hence, the non-controlling interest, which includes all the shareholders of the subsidiary other than the parent entity, might actually represent more than 50 per cent (that is, the majority) of the shareholding of the subsidiary. (Deegan/Ward 2013: 637)
}

As a majority of shareholders (i.e. owners) can have a non-controlling interest in a company, the Danish translation (which is formally equivalent to minority interest) is not convincing, but the authors of the English-Danish accounting dictionary, Engelsk-Dansk Regnskabsordbog, had to deal with this problem. They decided to write a definition that is directly based on the official one, to suggest a more precise Danish equivalent (e.g. ikke-kontrollerende interesse), to present the misleading equivalent as a synonym, and to include a lexical note explaining why the official Danish translation (i.e. minoritetsinteresse) is misleading, as shown in Figure 4.

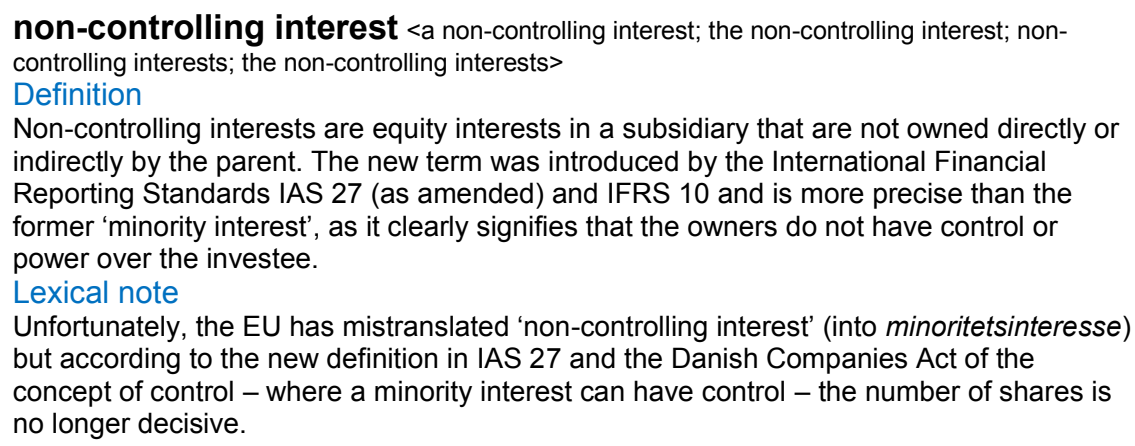

ikke-kontrollerende interesse (IAS/IFRS) <en ikke-kontrollerende interesse; den ikkekontrollerende interesse; ikke-kontrollerende interesser; de ikke-kontrollerende interesser> Synonyms

minoritetsinteresse (IAS/IFRS)

Figure 4. Definition, suggested equivalent and lexical note explaining mistranslation in international standard in Engelsk-Dansk Regnskabsordbog

The lexical note in Figure 4 explains why the lexicographers recommend the use of a Danish equivalent other than the official one by relating the suggested equivalent directly to the definition of the new concept and the English term. This may be compared to the less helpful treatment of the term non-controlling interest in Fars Engelska Ordbok, which merely presents two Norwegian translations (i.e. innehav utan bestämmande inflytande and minoritetsinteresse) and leaves it to the users to discover the conceptual difference. Mistranslations of regulatory texts may be difficult to deal with for lexicographers and so is the fact that the structural set-up of the economic domain in two cultures do not exactly overlap. 


\subsection{Structural incongruence complicates translation}

When the organisational structures of a subject-field differ from one another in two cultures or jurisdictions, such differences are important to lexicographers and translators alike. It should be appreciated that this concerns the meaning of concepts and the associated terms as well as differences in concept systems. Lexicographers may consider identifying relevant differences in meaning as such differences affect the writing of definitions; the discovery and lexicographic treatment of structural differences also require considerable factual competence, as explained by Evans et al. (2011: 21-22):

\section{[...] the meaning of accounting terms depends on the respective accounting system, rather than on any linguistic properties, and translatability of accounting terminology depends on how closely the ac- counting systems of source and target language are related.}

The significance of incongruence in relation to translation of economic texts is further accentuated by Dahlgren/Nilsson (2012: 55), who argue that "the crucial problem with translations is the situation where the meaning of structural components of one language does not match the meaning in another". The challenge facing lexicographers is then to deal with such structural differences in concept systems in ways that can help translators solve their translation problems, for instance when one concept in the source language corresponds to two concepts in the target language (a one-to-many relation). Lexicographers of a Danish-English dictionary of economics may elect to include explicit notes to the equivalents explaining their limited range of use based on an onomasiological approach; see Figure 5.

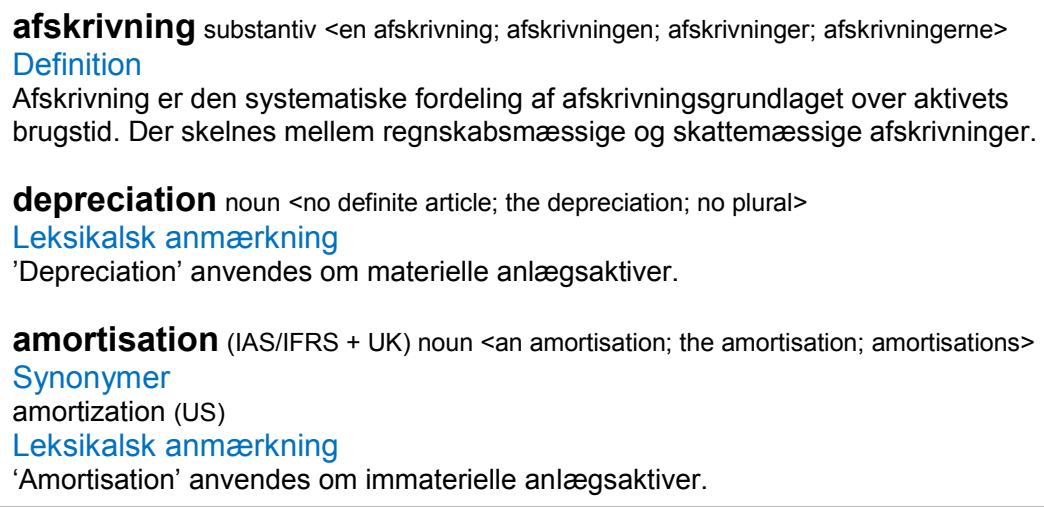

Figure 5. Notes explaining the limited meanings of two equivalents in Danish-English translation dictionary

The lexical notes following the two English equivalents in Figure 5 explain that depreciation is used with tangible assets (also referred to as property, plant and equipment), while amortisation is used with intangible assets; the Danish concept of afskrivning covers both types of asset. This solution enables lexicographers to inform translators about the differences in conceptual systems and relations in connection with the source-language and target-language concepts and how these manifests themselves, conceptually as well as terminologically (compare and contrast the solutions adopted in Figures 1 and 2). It should be noted that structural differences in the domain of two cultures may be accompanied by differences in language structures.

\subsection{Compound words require complex knowledge}

The combination of several linguistic units to denote single referents, often called compounds and compound words, may cause difficulties for lexicographers and translators. Petcovici/Ciortea (2012) discuss the importance of compounds and their translation in economic contexts and find, for instance, that economic discourse contains relatively many compounds and that compounds 
in the source language may correspond to formally different compounds in the target language. In order to provide translators with the best help possible, lexicographers should lemmatise compounds in their dictionaries of economics, because translators cannot be expected to know when and how target-language compounds differ from source-language ones. Compounding in connection with translation is complex, as noted in the literature:

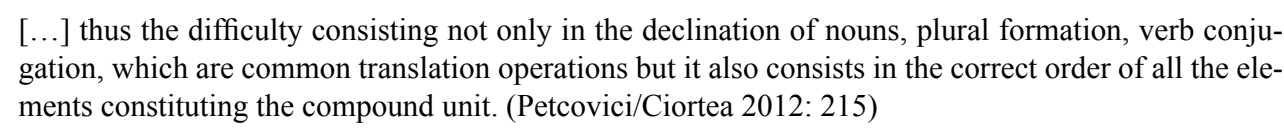

In English, compounds may be written as separate words, as words joined by hyphens, or as single words according to more or less established rules. Other languages, for example Danish and German, tend consistently to write compounds as single words according to fixed rules: The English compound word consumer price index is called forbrugerprisindeks in Danish and Verbraucherpreisindex in German; this may be compared to the equivalent French compound unit indice des prix à la consummation. The French compound highlights another problem, namely the different order of words, and the following short list shows Danish and English compound units with different word order:
a) afhoendelsesgevinst = gain on disposal
b) efterspørgselselasticitet $=$ elasticity of demand
c) produktionsfaktor $=$ factor of production
d) regnskab til brug for offentligheden = general purpose financial statement
e) direkte, udenlandsk investering = foreign direct investment
f) inflationshommende $=$ counter-inflationary

In the above list, a), b) and c) show that the English compounds have reverse word order compared with the Danish compounds; in d) the Danish term is a noun modified by a prepositional phrase; in e) the word order in the Danish term is partially reversed compared to the English word order; and in f) the English term is written as a hyphenated compound with reversed order of words. Lexicographers should carefully consider lemmatising such compound units in their dictionaries, because translators cannot be expected to know exactly how to write the target-language compound unit in every case; not even if the individual words "look identical" in the two languages can translators rely on word-for-word translation. The translation of compound units become even more complex when the two languages use different terms for the same concept, and the following list contains English and Danish compounds using different terms:
a) net profit or loss $=$ resultat
b) share appreciation rights $=$ fantomaktie
c) investee $=$ virksomhed, der er investeret $i$
d) circular flow = økonomisk kredsløb
e) economies of scale $=$ stordriftsfordele

Firstly, in a) Danish uses a single word, and in b) writes the compound as a single word. Secondly, the Danish term in c) is a noun followed by a defining relative clause, and in d) refers to economic (not circular) flow, while the Danish term in e) literally reads "large-operation benefits" with a reversed order of words. An examination of Engelsk-norsk økonomisk-juridisk ordbok reveals that it includes 2 of the 5 above English terms (i.e. circular flow and economies of scale) even though Norwegian translators need the same help as Danish translators.

Good translation dictionaries contain various types of compounds and help translators cope with this type of challenge resulting from different ways in which languages allow writers to pro- 
duce correct economic texts. Figure 6 illustrates how lexicographers may provide help to translate compound units when the source and the target language create terms as well as phrases differently.

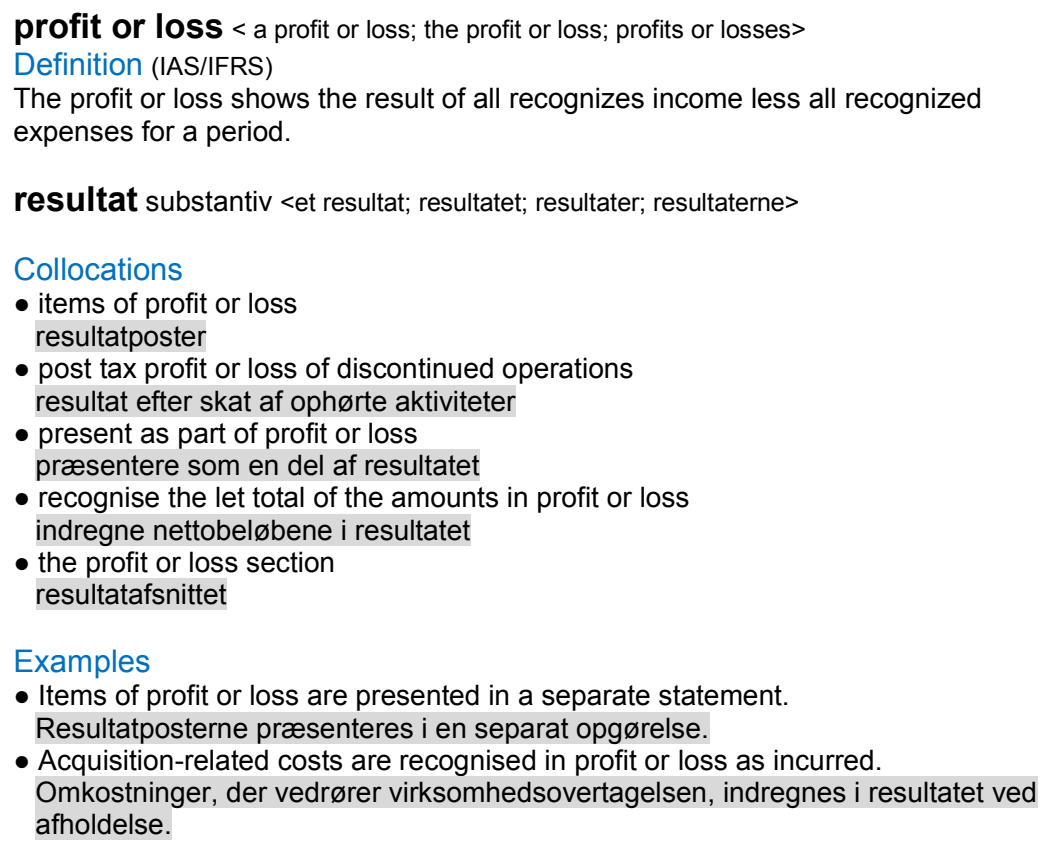

- Acquisition-related costs are recognised in profit or loss as incurred. Omkostninger, der vedrører virksomhedsovertagelsen, indregnes i resultatet ved afholdelse.

Figure 6. Help to translate compound units; excerpt from Engelsk-Dansk Regnskabsordbog

The dictionary article in Figure 6 explicitly shows the different inflectional paradigms of the English and the Danish terms, and the article provides further translation help by showing collocations and example sentences that illustrate different ways in which to translate the English term in specific contexts. In addition to compounding, translation problems may result from the fact that English comes in many varieties.

\subsection{Knowledge of English varieties is essential in translation}

English has almost become the lingua franca in international economic communication, but English is not just English. As pointed out by Gerzymisch-Arbogast (2008: 26), "Term systems and most importantly, knowledge systems may be differently structured interculturally, i.e. their 'setup' may vary by language and culture". Despite harmonisation and standardisation efforts in the European Union, and other supranational and international organisations, there is no universally accepted language policy for English economic terminology, and the English used in, for instance, the International Financial Reporting Standards varies. A closer study shows that the IFRSs use mainly American terminology but also British terminology and consistently apply British spelling (Nielsen/Mourier 2005: 89). In this light, dictionaries intended to help translators with English economic terminology should reflect this plurality of elements found in economic terminology. Lexicographers should therefore select different English varieties as lemmas and equivalents in their dictionaries, in particular those representing international, supranational, US English and UK English terms. Figure 7 illustrates how this may be done in a Danish-English dictionary. 


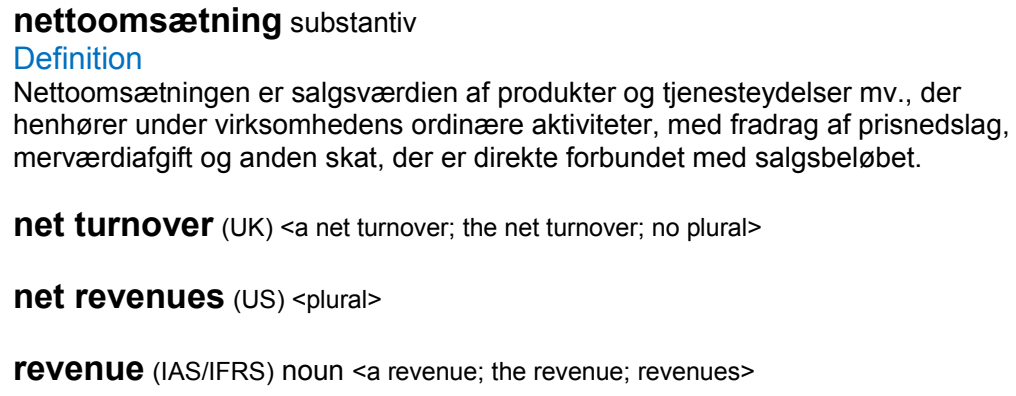

Figure 7. Dictionary article showing three varieties of English as equivalents of a single Danish term

The three equivalents presented in Figure 7 are clearly marked as English varieties (UK, US and IAS/IFRS, respectively) so that translators can select the one that is appropriate for their translations. By including inflectional paradigms, lexicographers can also show differences in grammar and usage, thus facilitating the translation process. Grammar and usage notes may help translators solve problems with single words but other translation problems may require information about units larger than words.

\subsection{Good dictionaries treat differences in language structures}

Different languages allow different kinds of structure for compound units, collocations, phrases etc. Translators of economic texts should be made aware of such structural differences and options in the two languages concerned, and lexicographers can use collocations and phrases to present such information explicitly and in the relevant contexts. It is important that translators become aware of the different language structures as they are not likely to be familiar with the differences and options available in the target language; see Figure 8.

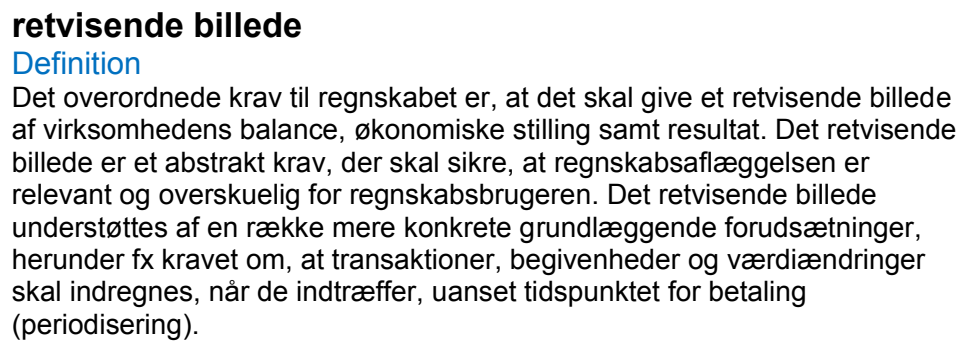

Det overordnede krav til regnskabet er, at det skal give et retvisende billede af virksomhedens balance, økonomiske stilling samt resultat. Det retvisende billede er et abstrakt krav, der skal sikre, at regnskabsaflæggelsen er relevant og overskuelig for regnskabsbrugeren. Det retvisende billede understøttes af en række mere konkrete grundlæggende forudsætninger, herunder fx kravet om, at transaktioner, begivenheder og værdiændringer skal indregnes, når de indtræffer, uanset tidspunktet for betaling (periodisering).

true and fair view $(\mathrm{UK})<\mathrm{a}$ true and fair view; the true and fair view; no plural>

fair presentation (IAS(IFRS + US) <a fair presentation; the fair presentation; no plural>

Kollokationer

- opfylde kravet om et retvisende billede

meet the requirement of a true and fair view (UK)

meet the fair presentation requirement (IAS(IFRS + US)

- oplysninger af betydning for det retvisende billede

information of importance to the true and fair view (UK)

information of importance to the fair presentation (IAS/IFRS + US)

Figure 8. Excerpt from Dansk-Engelsk Regnskabsordbog with equivalents and phrases showing different language structures in the source and target languages

The first Danish phrase in Figure 8 contains a noun modified by a prepositional phrase (kravet om et retvisende billede) and there are two translation options showing intercultural variety. In British English the phrase contains a similar structure (the requirement of a true and fair view), while the 
IAS/IFRS and American phrase contains a compound noun (the fair presentation requirement). This article explicitly shows the different structures available in the target language depending on whether the phrase is translated into British, American or international English. The second phrase also shows a grammatical difference between Danish and English concerning a word other than the lemma and equivalent: The Danish word oplysninger is countable and is shown in the plural, whereas the equivalent English word (information) is uncountable. Non-specialised and student translators will likely be unaware of this difference, so lexicographers should consider showing differences in language structures, for instance in phrases containing the normal occurrence of terms and words in economic contexts.

\section{Concluding remarks}

Dictionaries of economics are important for translating economic texts into or from English, and for producing economic texts in English as a foreign language. Modern lexicography has moved away from the narrow focus on words presented on a linguistically inspired semasiological basis and adopted a broad scope of application including a terminologically inspired onomasiological approach so that lexicographic products deal with words, terms, concepts, facts and practical matters. When they have established a sound theoretical and practical basis for their dictionaries and placed them in a functional framework, lexicographers have a workable point of departure for making economic translation dictionaries. It is then necessary to identify and analyse the factual, linguistic and pragmatic user needs as well as the stages involved in translating economic texts into or from English. The dictionaries need to include data about Danish, British, American, supranational and international economic concepts and terms, their grammatical properties, and their potential for being combined with other lexical units in collocations, phrases and sentences in order to meet user needs. Data that deal with these aspects are necessary for novice as well as seasoned translators who translate subject-specific and register-specific texts into or from a foreign language, and the data are relevant for the various stages in translation in the decoding, transfer and encoding phases as well as at the macro- and micro-levels of text production.

The theoretical aspects discussed and illustrated by examples of possible lexicographic solutions to the challenges of economic translation together with the needs of translators show the importance of having a sound theoretical and practical basis when designing and making dictionaries with communicative functions. The dictionaries provide help to translators in some of those situations in which research has found that they require help in translating domain-specific concepts and texts. Consequently, dictionaries of economics for translation may be described as lexicographic information tools that deal with words, concepts, terms, facts and practical matters in a single field or a sub-field and that have been designed to help users decode source-language texts, transfer meaning and write target-language texts as part of a translation process within the field of economics.

\section{References}

Andersen, Birger/Fuertes-Olivera, Pedro A. 2009: The Application of Functional Theory to the Classification of English Monolingual Business Dictionaries. In Lexicographica 25, 213-239.

Baskerville, Rachel/Evans, Lisa 2011: The darkening glass: Issues for translation of IFRS. Edinburgh: The Institute of Chartered Accountants of Scotland.

Bell, Roger T. 1991: Translation and Translating. Theory and Practice. London: Longman.

Bergenholtz, Henning/Tarp, Sven 2010: LSP Lexicography or Terminography? The Lexicographer's Point of View. In Fuertes-Olivera, Pedro A. (ed.), Specialised Dictionaries for Learners. Berlin: Walter de Gruyter, 27-38.

Bowker, Lynne 2012: Meeting the needs of translators in the age of e-lexicography: Exploring the possibilities. In Granger, Sylviane/Paquot, Magali (eds.), Electronic Lexicography. Oxford: Oxford University Press, 379-397.

Chifane, Christina 2012: Equivalence versus non-equivalence in economic translation. In Management Strategies Journal 18(4), 74-82. 
Dahlgren, Jörgen/Nilsson, Sven-Arne 2012: Can Translations Achieve Comparability? The Case of Translating IFRSs into Swedish. In Accounting in Europe 9(1), 39-59.

Deegan, Craig/Ward, Anne M. 2013: Financial Accounting and Reporting. An International Approach. Maidenhead: McGraw-Hill Education.

Evans, Lisa/Baskerville, Rachel F./Nara, Katariina 2011: Colliding worlds: language translation in accounting and other disciplines. In Applied Accounting - Practitioner eJournal 02/2011 [online]. DOI:10.2139/ssrn.1623310 (accessed 20 January 2015).

Far 2011: Fars Engelska Ordbok, svensk-engelsk och engelsk-svensk, $14^{\text {th }}$ edn. Stockholm: Far Akademi.

Felber, Helmuth 1984: Terminology Manual. Paris: Unesco.

Felber, Helmuth/Schaeder, Burkhard 1998: Typologie der Fachwörterbücher. In Hoffmann, Lothar/Kalverkämper, Hartwig/Wiegand, Herbert E., together with C. Galinski and Hüllen, Werner (eds.), Fachsprachen: Ein internationales Handbuch zur Fachsprachenforschung und Terminologiewissenschaft/International Handbook of SpecialLanguage and Terminology Research, Bd./Vol. 2. Berlin: Walter de Gruyter, 1725-1743.

Gerzymisch-Arbogast, Heidrun 2008: Fundamentals of LSP Translation. In Mutra 2: 7-64.

Greko, Kim 2012: Assessing Specialized Translation in Academic Contexts: A Case Study. In Traduzione e riscrittura 11, 116-127.

Hansen, Einar/Lind, Åge 2008: Engelsk-norsk økonomisk-juridisk ordbok. Oslo: Cappelen Akademisk Forlag.

Hatim, Basil/Mason, Ian 1997: The Translator as Communicator. London: Routledge.

International Accounting Standards Board 2009: International Accounting Standard 27 - Consolidated and Separate Financial Statements. London: International Accounting Standards Committee Foundation.

International Accounting Standards Board 2011a: International Financial Reporting Standard 10 - Consolidated Financial Statements. London: International Accounting Standards Committee Foundation.

International Accounting Standards Board 2011b: International Financial Reporting Standard 11 - Joint Arrangements. London: International Accounting Standards Committee Foundation.

Johnson, Samuel 1755: Dictionary of the English Language. London: J. and P. Knapton.

Kageura, Kyo 2015: Terminology and lexicography. In Kockaert, Hendrik J./Steurs, Frieda (eds.), Handbook of Terminology, Volume 1. Amsterdam: John Benjamins, 45-59.

Károly, Adrienn 2011: Translation competence and translation performance: Lexical, syntactic and textual patterns in student translations of a specialized EU genre. In English for Specific Purposes 31, 36-46 [online]. Doi:10.1016/j. esp.2011.05.005 (accessed 19 November 2014).

Marsen, Sky 2013: Professional Writing, $3^{\text {rd }}$ edn. Basingstoke: Palgrave Macmillan.

Mossop, Brian 2014: Revising and Editing for Translators, $3^{\text {rd }}$ edn. Abingdon: St. Jerome Publishing.

Newmark, Peter 1988: A Textbook of Translation. Hemel Hempstead: Prentice Hall.

Nielsen, Sandro 1990: Contrastive Description of Dictionaries Covering LSP Communication. In Fachsprache/International Journal of LSP 3-4, 129-136.

Nielsen, Sandro 2006: Monolingual Accounting Dictionaries for EFL Text Production. In Ibérica 12, 43-64 [online]. http//www.aelfe.org/documents/04-Nielsen.pdf (accessed 08 October 2014).

Nielsen, Sandro 2011: Function- and user-related definitions in online dictionaries. In Kartashkova, Faina I. (ed.), Ivanovskaya leksikografischeskaya shkola: traditsii i innovatsii [Ivanovo School of Lexicography: Traditions and Innovations]: A Festschrift in Honour of Professor Olga Karpova. Ivanovo: Ivanovo State University, 197-219.

Nielsen, Sandro/Mourier, Lise 2007: Design of a Function-based Internet Accounting Dictionary. In Gottlieb, Henrik/ Mogensen, Jens E. (eds.), Dictionary Visions, Research and Practice. Amsterdam: John Benjamins, 119-135.

Nielsen, Sandro/Mourier, Lise/Bergenholtz, Henning 2012a: Den Engelsk-Danske Regnskabsordbog. Odense: ordbogen.com. http://www.ordbogen.com

Nielsen, Sandro/Mourier, Lise/Bergenholtz, Henning 2012b: Den Dansk-Engelske Regnskabsordbog. Odense: Ordbogen.com. http//www.ordbogen.com

Parkinson, Dilys (ed.) 2005. Oxford Business English Dictionary for learners of English. Oxford: Oxford University Press.

Petcovici, Tania/Ciortea, Raluca 2012: Translation and Transfer of the European Economic Reality. In Annals. Economic Science Series XVIII, 215-222.

Smith, Adam 1972: Supermoney. New York: Random House.

Stolze, Radegundis 2003: Vagueness in Economic Texts as a Translation Problem. In Across Languages and Cultures 4(2), 187-203. 
Suonuuti, Heidi 1997: Guide to Terminology. Helsinki: Tekniikan Sanastokeskus.

Tarp, Sven/Bothma, Theo J.D. 2013: An Alternative Approach to Enlightenment Age Lexicography: The Universal Dictionary of Trade and Commerce. In Lexicographica 29, 222-284.

Wiegand, Herbert E. 1988: Was eigentlich ist Fachlexikographie? Mit Hinweisen zum Verhältnis von sprachligem und enzyklopädischem Wissen. In Munske, Hans H./von Polenz, Peter/Reichmann, Oskar/Hildebrandt, Rainer (eds.), Deutscher Wortschatz. Lexikologische Studien. Ludwig Erich Schmitt zum 80. Geburtstag von seinen Marburger Schülern. Berlin: Walter de Gruyter, 371-409. 